\title{
Greenhouse Gas Emissions From Native and Non-native Oysters
}

\author{
Gretchen J. McCarthy ${ }^{1 *}$, Nicholas E. Ray ${ }^{2}$ and Robinson W. Fulweiler ${ }^{1,2 *}$ \\ ${ }^{1}$ Department of Earth and Environment, Boston University, Boston, MA, United States, ${ }^{2}$ Department of Biology, Boston \\ University, Boston, MA, United States
}

OPEN ACCESS

Edited by:

Elena Tricarico,

University of Florence, Italy

Reviewed by:

Nadescha Zwerschke,

British Antarctic Survey (BAS),

United Kingdom

Camilla Bertolini,

Ca' Foscari University of Venice, Italy

${ }^{*}$ Correspondence:

Gretchen J. McCarthy

gjmmcc@bu.edu

Robinson W. Fulweiler

rwf@bu.edu

Specialty section:

This article was submitted to

Conservation,

a section of the journal

Frontiers in Environmental Science

Received: 17 July 2019 Accepted: 02 December 2019

Published: 19 December 2019

Citation:

McCarthy GJ, Ray NE and Fulweiler RW (2019) Greenhouse Gas

Emissions From Native and Non-native Oysters.

Front. Environ. Sci. 7:194. doi: 10.3389/fenvs.2019.00194
Non-native species introductions are associated with a range of ecosystem changes such as habitat destruction, competition with native species, and biodiversity losses. Less well known is the role non-native species play in altering biogeochemical processes, such as the emission of greenhouse gases (GHGs). In this study we used laboratory incubations to compare seasonal (spring, summer, fall) emissions of the GHGs nitrous oxide $\left(\mathrm{N}_{2} \mathrm{O}\right)$, methane $\left(\mathrm{CH}_{4}\right)$, and carbon dioxide $\left(\mathrm{CO}_{2}\right)$ from native (Crassostrea virginica) and non-native (Ostrea edulis) oysters collected from a northern temperate estuary (Duxbury Bay, Massachusetts, USA). We observed strong seasonal signals in GHG fluxes, where $C$. virginica was the higher $\mathrm{GHG}$ emitter, and produced on average twice as much $\mathrm{N}_{2} \mathrm{O}\left(0.39 \mathrm{nmol} \mathrm{g}^{-1}\right.$ dry tissue weight $\left.\mathrm{hr}^{-1}\right)$ and 20 times as much $\mathrm{CH}_{4}(1.31 \mathrm{nmol}$ $\left.\mathrm{g} \mathrm{DTW}^{-1} \mathrm{hr}^{-1}\right)$ compared to 0 . edulis $\left(0.16 \mathrm{nmol} \mathrm{N}_{2} \mathrm{O} \mathrm{g} \mathrm{DTW}{ }^{-1} \mathrm{hr}^{-1}\right.$ and $0.07 \mathrm{nmol} \mathrm{CH}_{4}$ $\left.\mathrm{g} \mathrm{DTW}^{-1} \mathrm{hr}^{-1}\right)$. C. virginica also had significantly $(\mathrm{p}<0.001)$ higher summer maximum production rates of $\mathrm{CO}_{2}$ compared to 0 . edulis (53.4 $\mu \mathrm{mol} \mathrm{g} \mathrm{DTW}{ }^{-1} \mathrm{hr}^{-1}$ and $45.4 \mu \mathrm{mol}$ $\mathrm{g} \mathrm{DTW}^{-1} \mathrm{hr}^{-1}$, respectively). Despite these differences, chlorophyll-a consumption rates between the species were similar $(p=0.95)$. These results suggest that the non-native O. edulis is a lower GHG emitter than the native $C$. virginica and highlight that, at least in terms of GHG emissions, this non-native species introduction may not be detrimental to the environment.

Keywords: methane, nitrous oxide, exotic species, coastal biogeochemistry, carbon dioxde

\section{INTRODUCTION}

The introduction of non-native species to both terrestrial and aquatic ecosystems is a growing global concern (Vitousek et al., 1996; Castro-Díez et al., 2019; Seebens et al., 2019). In some cases, these non-native species have led to dramatic declines in biodiversity (Molnar et al., 2008) and displacement of native species (Byers, 2000; Rossong et al., 2006). In other cases, they appear to have little to no impact (e.g., Grosholz, 2005). The effect of non-native species on marine ecosystems is not well constrained. A recent meta-analysis examined the impact of 76 exotic marine species (just $6 \%$ of the listed exotics) on marine communities and found that these species caused a small, but significant decrease in ecological variables such as primary producers and multi-trophic assemblages (Anton et al., 2019). Of note, they reported that mollusks were one of just four taxonomic groups related to declines in the ecological function of many native marine taxa (Anton et al., 2019). This finding agrees with a variety of studies on the ecological impacts of exotic bivalves (Sousa et al., 2009; Helmer et al., 2019). One of the best-known examples is the introduction of the Pacific oyster, Magallana gigas (formerly Crassostrea gigas) to Europe. $M$. gigas has reportedly changed sediment properties (Green et al., 2012), shifted macrozoobenthic 
communities (Kochmann et al., 2008), and altered food web structure (Souchu et al., 2001). Alternatively, other studies have reported minimal ecosystem impacts following the introduction of M. gigas (Krassoi et al., 2008; Wilkie et al., 2012; Zwerschke et al., 2016).

In North America, the European Flat Oyster (Ostrea edulis) was intentionally introduced to the state of Maine (United States, US) with aims to establish an oyster fishery in the 1950s (Laing et al., 2006). Today, O. edulis has expanded its range south, and is now established from Maine to Rhode Island (FAO, 2009). The impact of this non-native species on ecosystem function is largely unknown. In this study, we compared emissions of nitrous oxide $\left(\mathrm{N}_{2} \mathrm{O}\right)$ and methane $\left(\mathrm{CH}_{4}\right)$ from $\mathrm{O}$. edulis and C. virginica, as previous research has shown that bivalves can be sources of these two powerful greenhouse gases (GHG) which have global warming potentials 298 and 25 times more than carbon dioxide $\left(\mathrm{CO}_{2}\right)$, respectively (Myhre et al., 2013).

Microbial processes occurring on (e.g., shell epibiota), or within (e.g., mantle cavity, digestive system) oysters can produce or consume $\mathrm{N}_{2} \mathrm{O}$. For example, both nitrification (which can produce $\mathrm{N}_{2} \mathrm{O}$ ) and denitrification (which can produce or consume $\mathrm{N}_{2} \mathrm{O}$ ) occur on $C$. virginica shells, although shell denitrification rates are higher from living oysters (Caffrey et al., 2016). Arfken et al. (2017) used a metabolic approach to demonstrate that the relative abundance of denitrifying bacteria was higher in C. virginica whole oysters and shells compared to nearby sediments, and concluded that oysters appear to be denitrifying "hot spots." Denitrification has also been confirmed in the epibiota of the Sydney Rock Oyster (Saccostrea glomerata; Erler et al., 2017). Most recently, significant $\mathrm{N}_{2} \mathrm{O}$ emissions have been observed from the $C$. virginica digestive system (Ray et al., 2019a). Additionally, experimental incubations of living C. virginica individuals showed oysters switched from being a $\mathrm{N}_{2} \mathrm{O}$ sink to a $\mathrm{N}_{2} \mathrm{O}$ source when incubation water was enriched with dissolved inorganic nitrogen (DIN; Gárate et al., 2019). Together, these studies demonstrate that oysters support dynamic microbial ecosystems capable of altering $\mathrm{N}_{2} \mathrm{O}$ fluxes in coastal ecosystems.

Compared to $\mathrm{N}_{2} \mathrm{O}$, we know much less about $\mathrm{CH}_{4}$ cycling in oysters. Previous research shows that bivalve gut cavities can house archaeal methanogenic symbionts and methanotrophs can live in the mantle cavities of bivalves (Childress et al., 1986; Bonaglia et al., 2017). Thus, it seems reasonable to propose that oysters too may host $\mathrm{CH}_{4}$ producing and consuming organisms. However, a recent study reported only very low $\mathrm{CH}_{4}$ emissions from C. virginica $\left(0.00038 \pm 0.00046 \mu \mathrm{mol} \mathrm{CH}_{4} \mathrm{gDW}^{-1} \mathrm{hr}^{-1}\right)$, rates not statistically different from zero (Ray et al., 2019b). Thus, $\mathrm{CH}_{4}$ emissions from oysters are largely unknown, but potentially small.

Within this context, we quantified the net fluxes of $\mathrm{N}_{2} \mathrm{O}$ and $\mathrm{CH}_{4}$, as well as chlorophyll-a by $C$. virginica and $O$. edulis over an annual temperature cycle. We also measured dissolved oxygen uptake and used it to estimate $\mathrm{CO}_{2}$ release for each species using a respiratory quotient from the literature (Galtsoff et al., 1964). Our primary goals were to quantify GHG emissions from a native (C. virginica) and non-native (O. edulis) oyster species, to examine how these GHG fluxes varied with environmental parameters (e.g., temperature, salinity) and oyster characteristics (i.e., dry tissue and shell weight), and to add to the growing literature on the potential role non-native species play in altering biogeochemical cycling. We hypothesized that each species would release $\mathrm{N}_{2} \mathrm{O}$, but little to no $\mathrm{CH}_{4}$, and that GHG fluxes would increase with temperature.

\section{METHODS}

\section{Site Description}

We collected oysters and site water from Duxbury Bay (Massachusetts, USA) on six occasions between September 2017 and August 2018 (Figure S1). Duxbury Bay is a shallow system with an average water depth of $3 \mathrm{~m}$ at high tide, and several exposed mudflats at low tide (Feinman et al., 2018). The system exchanges $70 \%$ of its water volume with the Atlantic Ocean twice daily (Lawson, 2011).

\section{Sample Collection}

During each sampling event, we measured water column dissolved oxygen (DO) concentration, $\mathrm{pH}$, salinity, and temperature using a Hach HQ40d, equipped with LDO101, PHC301, and CDC401 probes (Table S1). We measured water column chlorophyll-a concentrations in duplicate with a $60 \mathrm{~mL}$ polypropylene syringe and glass fiber filters (Whatman $\mathrm{GF} / \mathrm{F}$, $0.70 \mu \mathrm{m}$ pore size). Chlorophyll-a filters were stored at $-80{ }^{\circ} \mathrm{C}$ until analysis.

Upon collection, oysters were immediately placed in a cooler filled with site water. We also collected unfiltered site water in carboys. Both were transported back to the laboratory, and kept in a dark environmental chamber set to in situ field temperature. Once in the environmental chamber, air-stones were placed in the oyster filled cooler and the carboys and were gently bubbled overnight ( $>12 \mathrm{~h}$ ) to keep the overlaying water oxygenated.

\section{Oyster GHG Incubation}

$C$. virginica and $O$. edulis individuals were randomly assigned to an incubation chamber filled with site water using a random number generator (Randomness and Integrity Services Ltd.). Each treatment (i.e., native: C. virginica and non-native: $O$. edulis) had three clear polyvinyl chloride (PVC) chambers (2.106 L) per incubation. In cool months (September 2017, March 2018, April 2018, June 2018), we placed four oysters in each chamber. In warmer months (July 2018, August 2018) we placed three oysters in each chamber to ensure DO would not drop too rapidly during the incubation due to elevated oyster respiration. We changed the number of oysters used in summer incubations to reduce the risk of hypoxic conditions in the chambers during warm temperatures and higher rates of respiration. For each incubation, we also incubated triplicate chambers containing site water alone (i.e., water column control chambers) to account for any fluxes occurring in the water column.

Before sealing the chambers with gas tight lids, we collected samples for the initial chlorophyll-a concentrations in each chamber using the methods described above for chlorophyll-a collection in the field. We repeated this sampling at the end of the incubation. We then sealed each chamber without any 
air headspace using gas-tight acrylic lids equipped with inflow and outflow ports (Ray et al., 2019a). Magnetic stir bars fixed to the core tops provided gentle mixing of the overlying water $\left(\sim 40\right.$ revolutions $\left.\mathrm{min}^{-1}\right)$. Incubation time was determined by balancing the following criteria: achieving at least a $62.5 \mu \mathrm{M}$ $\left(2 \mathrm{mg} \mathrm{O}_{2} \mathrm{~L}^{-1}\right)$ drop in DO (Foster and Fulweiler, 2016) over the course of five sampling time points at intervals of $\sim 20-60 \mathrm{~min}$, and maintaining DO concentrations above the hypoxic threshold (>62.5; Heiss et al., 2012). DO concentrations were measured at three time points (initial, middle, and final) using an optical dissolved oxygen sensor (Hach LDO101). Gas samples for $\mathrm{N}_{2} \mathrm{O}$ and $\mathrm{CH}_{4}$ were collected in duplicate water samples at five time points allowing for overflow for each sample vials into $12 \mathrm{~mL}$ Labco Limited Exetainer ${ }^{\circledR}$ with gastight septa. Sample vials were filled from the bottom with $\sim 3$ times the overflow volume and preserved with $25 \mu \mathrm{L}$ of saturated zinc chloride solution (Ray et al., 2019b). These samples were immediately transferred to a refrigerator $\left(4-6^{\circ} \mathrm{C}\right)$ until further analysis.

During our six incubations, some chambers did drop below the hypoxic threshold. In the July incubation, all three of the $O$. edulis chambers went hypoxic, and in the August incubation, two O. edulis chambers went hypoxic. Regardless, our flux data remained linear, so we included these chambers in our analysis. Lights in the environmental chamber were left on during the gas incubations due to short sampling windows. At the start and end of incubations, we visually checked that oysters were open and actively filtering water.

Within $24 \mathrm{~h}$ of the incubation, we measured the shell length, width, and depth $(\mathrm{cm})$ of each oyster. We then shucked the oysters, weighed their shell and tissue wet mass (g), and placed them in a drying oven set to $60^{\circ} \mathrm{C}$ until a constant weight was reached.

\section{Calculating Shell Surface Area}

In order to estimate shell surface area, we used photogrammetric processing software (Agisoft Metashape Professional 1.5.2) to create three-dimensional mesh renderings of a subset of specimens ( $n=36$ for $C$. virginica and $n=32$ for O. edulis). Each mesh was crafted from a series of $\sim 50$ images of each specimen top, curved shell only, taken with a digital camera.

\section{Sample Analysis and Flux Calculations}

Chlorophyll-a analysis was conducted by extracting the sample filter in $10 \mathrm{~mL}$ of $90 \%$ acetone, followed by fluorometric analysis using a Turner Model AU-10 Digital Fluorometer with Optical Kit P/N 10-040R (Arar and Collins, 1997; Carey and Fulweiler, 2013).

We measured concentrations of dissolved $\mathrm{N}_{2} \mathrm{O}$ and $\mathrm{CH}_{4}$ gas directly using a headspace equilibration technique followed by analysis of the sample headspace using gas chromatography (GC) following published methods (Kling et al., 1991; Foster and Fulweiler, 2016). All standard curves had $\mathrm{R}^{2} \geq 0.995$ for six data points used. The detection limits during sample analysis were $0.383 \mu \mathrm{M}$ for $\mathrm{N}_{2} \mathrm{O}$ and $5.188 \mu \mathrm{M}$ for $\mathrm{CH}_{4}$.

Flux rates of each GHG were determined by calculating the slope of the linear regression of analyte concentration over the incubation time (Giblin et al., 1997; Hopkinson et al., 1999; Heiss et al., 2012) A flux was only considered significant when $R^{2} \geq$
0.65 and $p<0.10$ (Prairie, 1996; Foster and Fulweiler, 2016). If these criteria were not met, the flux was determined to equal zero, and indicated that either no flux occurred, there was a balance between production and consumption processes in the chamber, or fluxes occurred at rates below the detection limit (Foster and Fulweiler, 2016). The resulting fluxes were scaled by total dry tissue mass and all GHG fluxes are reported as nmol hr-1 $\mathrm{g}$ $\mathrm{DTW}^{-1}$. Chlorophyll-a and DO flux rates were calculated as the difference in final and initial concentrations over the incubation time, scaled by total dry tissue mass, and are reported as $\mu \mathrm{mol}$ $\mathrm{hr}^{-1} \mathrm{~g} \mathrm{DTW}^{-1}$. We calculated oyster $\mathrm{CO}_{2}$ production using a respiratory quotient $(\mathrm{RQ})$ of 0.83 for C. virginica (Galtsoff et al., 1964) and O. edulis because we were unable to find an RQ value for O. edulis in the literature (Table S3). In all cases, a positive flux indicates production of an analyte by the oyster while a negative flux indicates the consumption of analyte from the water column by the oysters (Fulweiler et al., 2008; Heiss et al., 2012).

\section{Statistical Analysis}

All statistical analyses were conducted using $\mathrm{R}$ studio (version 3.4.4) and were considered statistically significant when $p \leq$ 0.05 . We compared shell area per g DTW, shell dimensions, and tissue and shell mass between species using Wilcoxon rank-sum tests. We compared whether fluxes were significantly differently from zero using one-sample Wilcoxon signed rank tests. Before comparing fluxes between species, we identified the distributions that best described each flux using the fitdistrplus package (Marie et al., 2015). $\mathrm{N}_{2} \mathrm{O}$ fluxes best fit a lognormal distribution, $\mathrm{CH}_{4}$ and chlorophyll-a fluxes were normally distributed, and $\mathrm{CO}_{2}$ fluxes best fit a gamma distribution.

To compare net fluxes between species we used a mixed model approach. In order to best meet model assumptions, we first shifted all of the $\mathrm{N}_{2} \mathrm{O}$ and $\mathrm{O}_{2}$ data so that all values were positive, and then applied a $\log$ transformation to the $\mathrm{N}_{2} \mathrm{O}$ data. $\mathrm{CH}_{4}$, $\mathrm{CO}_{2}$, and chlorophyll-a fluxes were not transformed. Next, we constructed a Generalized Linear Model (GLM) for each flux, using the lme4 package (Bates et al., 2015) with oyster species and temperature as fixed effects. For the $\mathrm{CO}_{2}$ data, we used a gamma family in the model. We then compared whether the two species differed using a pairwise least-square mean test of the GLM with the emmeans package (Lenth, 2018). Additionally, we tested whether fluxes differed between seasons by constructing models that included oyster species and season as fixed effects, and then compared seasons using pairwise least-square mean tests. We also compared fluxes between species using this model (Table S6).

Correlations between GHG fluxes and salinity, respiration, feeding rates, and shell characteristics for each species were calculated using Pearson correlation tests. We did not run correlations for shell surface area and GHG flux because we did not have area measurements for all of our specimens. We used Pearson correlation tests to quantify if any biotic (e.g., feeding rates, shell characteristics) or abiotic factors (e.g., salinity) we measured were related to GHG emissions from each species. Additionally, we tested for correlations between fluxes of the three GHGs to see if there were any common flux patterns. Finally, we used linear regressions to test if temperature could be used to predict the magnitude of GHG flux for each species. 


\section{RESULTS}

\section{Physical Characteristics of Oyster Species}

$C$. virginica and $O$. edulis shells had statistically different shell widths $(p<0.001)$ and depths $(p<0.001)$ but not shell lengths $(p=0.08)$. On average, $O$. edulis used in the experiment were longer (mean length of $8.93 \pm 0.25 \mathrm{~cm}$ ) than C. virginica (mean length $8.22 \pm 0.13$ ). O. edulis was also wider (mean width $8.25 \pm$ $0.15 \mathrm{~cm}$ ) than C. virginica with mean widths (mean width $5.78 \pm$ $0.13 \mathrm{~cm})$. However, C. virginica had a deeper cup $(2.19 \pm 0.07 \mathrm{~cm})$ than O. edulis $(1.91 \pm 0.06 \mathrm{~cm})$ (Tables S2, S4). The average dry tissue mass per gram dry shell mass (DTW per g DSW) was significantly different between treatments $(p<0.01)$ where $O$. edulis had more tissue per gram of shell than $C$. virginica (mean $0.11 \pm 0.02 \mathrm{DTW}_{\mathrm{g} \mathrm{DSW}}^{-1}$ and $0.08 \pm 0.01 \mathrm{DTW}^{\mathrm{g} \mathrm{DSW}}{ }^{-1}$, respectively). For the subset of shells we measured, shell surface area was not significantly different between species $(p=0.33)$. However, $C$. virginica had significantly $(p<0.001)$ more shell area per tissue mass $\left(110.34 \pm 8.7 \mathrm{~cm}^{2}\right.$ shell $\left.\mathrm{g} \mathrm{DTW}^{-1}\right)$ than $O$. edulis $\left(67.91 \pm 4.02 \mathrm{~cm}^{2}\right.$ shell $\left.\mathrm{g} \mathrm{DTW}^{-1}\right)$.

\section{GHG Fluxes and Correlation Analysis}

Both oyster species emitted $\mathrm{N}_{2} \mathrm{O}$ at rates significantly different from zero (C. virginica $p=0.02$ and $O$. edulis $p=0.02$ ). On average, C. virginica emitted more than twice as much $\mathrm{N}_{2} \mathrm{O}$ than $O$. edulis $\left(0.39 \pm 0.16 \mathrm{nmols} \mathrm{hr}^{-1} \mathrm{~g} \mathrm{DTW}^{-1}\right.$ and 0.16 $\pm 0.06 \mathrm{nmols} \mathrm{hr}^{-1} \mathrm{~g} \mathrm{DTW}^{-1}$, respectively), but these rates were not statistically different $(p=0.276)$. In general, net $\mathrm{N}_{2} \mathrm{O}$ production was observed during spring (March and April 2018) and fall (September 2017) while little $\mathrm{N}_{2} \mathrm{O}$ flux occurred during the summer (June, July and August 2018) (Figure 1A).
$\mathrm{N}_{2} \mathrm{O}$ fluxes were statistically higher in spring compared to summer $(p<0.01)$ or fall $(p=0.05)$, and higher in the fall compared to summer $(p<0.01)$ (Table S5). There was no significant relationship between $\mathrm{N}_{2} \mathrm{O}$ fluxes and temperature for either species (Figures 2A,B). Additionally, $\mathrm{N}_{2} \mathrm{O}$ fluxes were only correlated to salinity for $C$. virginica (Table 1) and to g DTW for O. edulis (Table 2; Figure S2).

Neither C. virginica $(p=0.06)$ nor O. edulis $(p=0.22)$ released $\mathrm{CH}_{4}$ at rates statistically different from zero when all incubations were pooled. $\mathrm{CH}_{4}$ fluxes also did not differ significantly between species $(p=0.08)$. Despite not being statistically significant, $C$. virginica produced, on average, more than twenty times as much $\mathrm{CH}_{4}$ as O. edulis (mean $1.31 \pm 2.62 \mathrm{nmol} \mathrm{hr}^{-1} \mathrm{~g} \mathrm{DTW}^{-1}$ and $0.07 \pm 1.41 \mathrm{nmol} \mathrm{hr}^{-1} \mathrm{~g} \mathrm{DTW}^{-1}$, respectively). Generally, $\mathrm{CH}_{4}$ release occurred during the summer (June, July and August 2018), while small rates of $\mathrm{CH}_{4}$ production, or oxidation, were observed during the spring (March and April 2018) and fall (September 2017) (Figure 1B), though these seasonal changes were not statistically different (Table S5). Similarly, temperature was not a significant predictor of $\mathrm{CH}_{4}$ flux (Figures 2C,D). C. virginica $\mathrm{CH}_{4}$ fluxes were positively correlated with $\mathrm{CO}_{2}$ fluxes (Table 1) while $\mathrm{CH}_{4}$ fluxes from O. edulis were not correlated any of the parameters we measured (Table 2; Figure S2).

$\mathrm{CO}_{2}$ production rates were not significantly different between C. virginica and O. edulis $(p=0.38)$ and mean rates of production were $24.77 \pm 18.88 \mu$ mols $\mathrm{hr}^{-1} \mathrm{~g} \mathrm{DTW}^{-1}$ and $19.44 \pm 14.52$

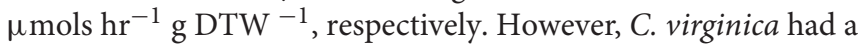
higher maximum production rate of $\mathrm{CO}_{2}$ than $\mathrm{O}$. edulis during the summer $\left(53.4 \mu\right.$ mols $\mathrm{hr}^{-1} \mathrm{~g} \mathrm{DTW}^{-1}$ and $45.4 \mu \mathrm{mols} \mathrm{hr}^{-1}$ g DTW $^{-1}$, respectively; Figure $1 C$ ). $\mathrm{CO}_{2}$ release was lower in the spring compared to summer $(p<0.01)$ or fall $(p<0.01)$,
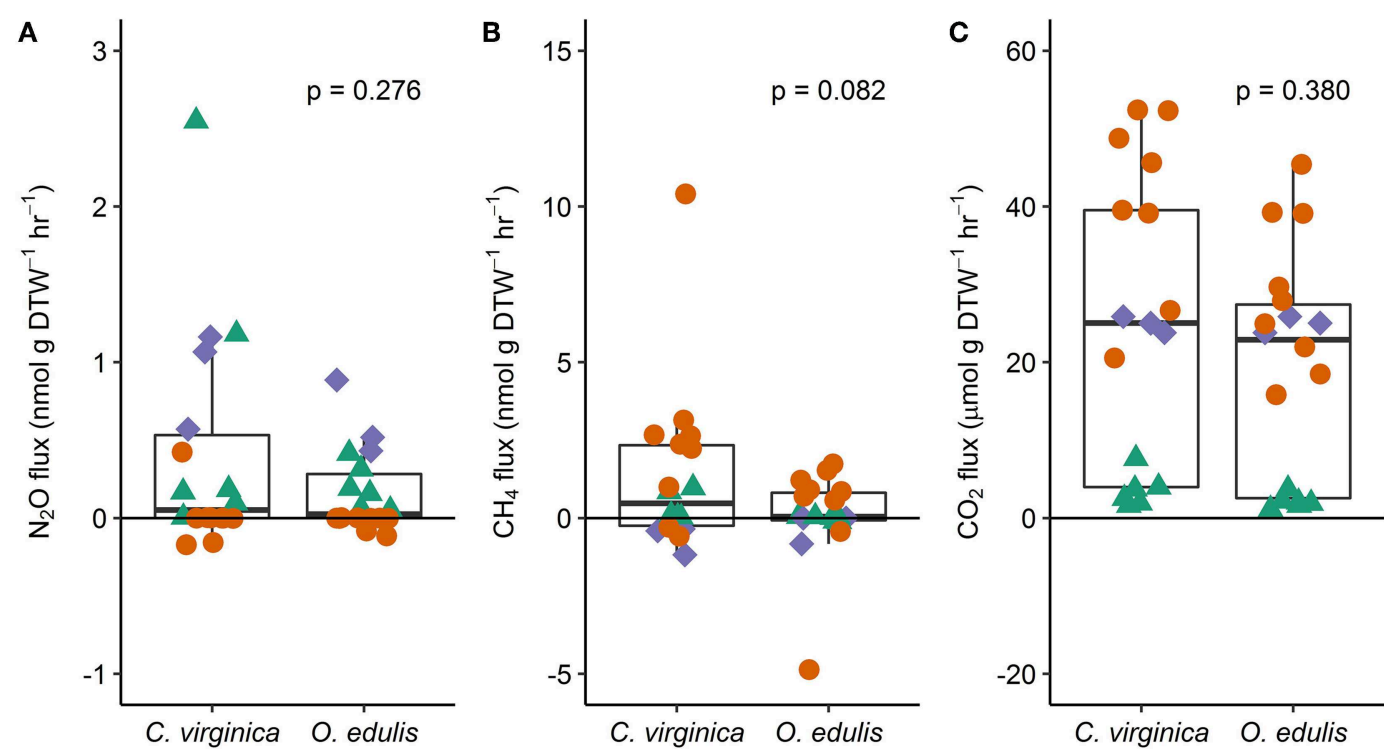

FIGURE 1 | Fluxes of nitrous oxide (A), methane (B), and carbon dioxide (C) from native (C. virginica) and non-native oysters (O. edulis); $n=18$ for each species and flux, except $n=17$ for $C$. virginica $\mathrm{CO}_{2}$ fluxes. $P$-values show the result of least squares means tests comparing the mean flux between the native and non-native oysters. Each point represents an individual flux measurement (spring: green triangles, summer: orange circles, and fall: blue diamonds). Points below the zero-line show net consumption, and points above show net production. 


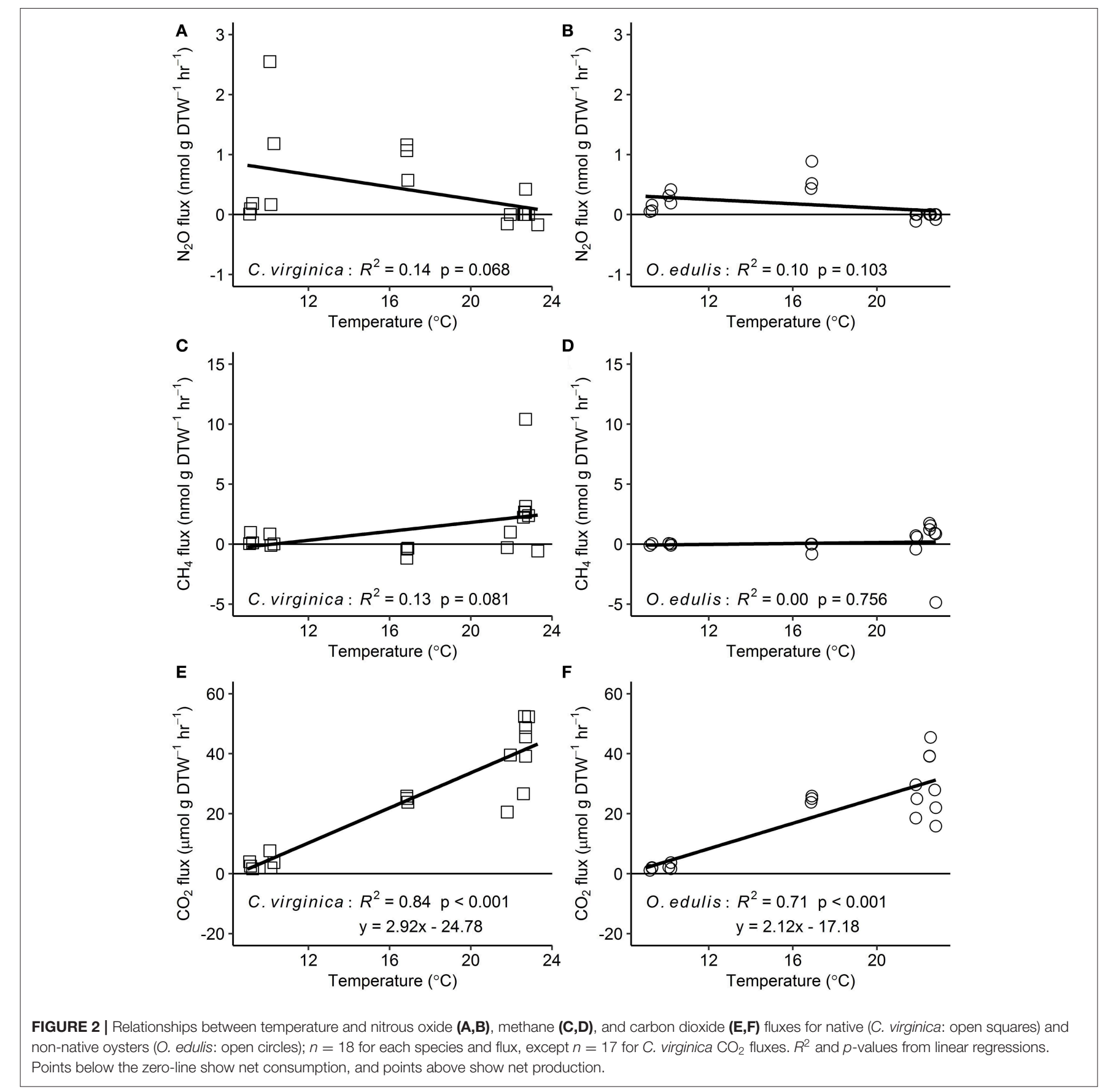

and there was no difference in $\mathrm{CO}_{2}$ release between summer and fall ( $p=0.31$ ) (Table S5). Temperature was a significant predictor of $\mathrm{CO}_{2}$ release from both species (Figures 2E,F). C. virginica $\mathrm{CO}_{2}$ production was positively correlated with $\mathrm{CH}_{4}$ flux and salinity (Table 1), while O. edulis $\mathrm{CO}_{2}$ production was positively correlated with salinity and negatively correlated with chlorophyll-a consumption (Table 2; Figure S2).

Chlorophyll-a consumption rates for $C$. virginica and $O$. edulis were both significantly different from zero $(p<0.01$ for each species), but were not significantly different between species $(p=0.95)$. Chlorophyll-a consumption was lower in the spring compared to summer $(p=0.03)$ or fall $(p=0.02)$, but consumption was not different between summer and fall $(p=$ 0.64) (Table S5). C. virginica chlorophyll-a consumption rates were negatively correlated with DTW (Table 2) and O. edulis chlorophyll-a consumption rates were negatively correlated to $\mathrm{CO}_{2}$ production and temperature (Table 2 ).

Pairwise comparisons between species using a model with season and species as fixed effects yielded the same results as the model with temperature and species as fixed effects (Table S6). 
TABLE 1 | Pearson correlations between greenhouse gas fluxes, g dry oyster tissue (DTW) and g dry oyster shell (DSW), and salinity for C. virginica.

\begin{tabular}{|c|c|c|c|c|c|c|c|}
\hline & $\mathrm{CO}_{2}$ flux & $\mathrm{CH}_{4}$ flux & $\mathrm{N}_{2} \mathrm{O}$ flux & Chl a flux & DTW & DSW & Salinity \\
\hline $\mathrm{CO}_{2}$ flux & 1.00 & $0.50(0.04)$ & $-0.34(0.19)$ & $-0.22(0.39)$ & $-0.08(0.77)$ & $-0.16(0.54)$ & $0.84(<0.01)$ \\
\hline $\mathrm{CH}_{4}$ flux & & 1.00 & $-0.14(0.58)$ & $0.05(0.86)$ & $-0.44(0.07)$ & $-0.45(0.06)$ & $0.31(0.21)$ \\
\hline Chl a flux & & & & 1.00 & $-0.72(0.001)$ & $-0.36(0.16)$ & $-0.46(0.06)$ \\
\hline
\end{tabular}

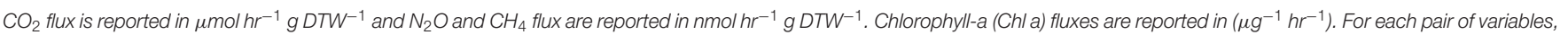
the top number represents the $r$-value while the value in parentheses beneath it is the $p$-value. Significant relationships ( $p \leq 0.05)$ are indicated in bold (except for 1:1 correlations).

TABLE 2 | Pearson correlations between greenhouse gas fluxes, g dry oyster tissue (DTW) and g dry oyster shell (DSW), and salinity for $O$. edulis.

\begin{tabular}{|c|c|c|c|c|c|c|c|}
\hline & $\mathrm{CO}_{2}$ flux & $\mathrm{CH}_{4}$ flux & $\mathrm{N}_{2} \mathrm{O}$ flux & Chl a flux & DTW & DSW & Salinity \\
\hline $\mathrm{CO}_{2}$ flux & 1.00 & $0.28(0.26)$ & $-0.16(0.05)$ & $-0.68(<0.01)$ & $0.09(0.73)$ & $-0.44(0.07)$ & $0.84(<0.01)$ \\
\hline $\mathrm{CH}_{4}$ flux & & 1.00 & $-0.08(0.76)$ & $-0.33(0.18)$ & $-0.16(0.53)$ & $-0.12(0.63)$ & $0.05(0.84)$ \\
\hline $\mathrm{N}_{2} \mathrm{O}$ flux & & & 1.00 & $0.17(0.51)$ & $0.80(<0.01)$ & $-0.18(0.46)$ & $-0.26(0.30)$ \\
\hline Chl a flux & & & & 1.00 & $0.10(0.70)$ & $0.05(0.85)$ & $-0.44(0.07)$ \\
\hline
\end{tabular}

$\mathrm{CO}_{2}$ flux is reported in $\mu \mathrm{mol} \mathrm{hr}^{-1} \mathrm{~g} D T \mathrm{~W}^{-1}$ and $\mathrm{N}_{2} \mathrm{O}$ and $\mathrm{CH}_{4}$ flux are reported in $\mathrm{nmol} \mathrm{hr}^{-1} \mathrm{~g} D T \mathrm{~W}^{-1}$. Chlorophyll-a (Chl a) fluxes are reported in $\left(\mu \mathrm{g}^{-1} \mathrm{hr}^{-1}\right)$. For each pair of variables, the top number represents the $r$-value while the value in parentheses beneath it is the $p$-value. Significant relationships $(p \leq 0.05)$ are indicated in bold (except for 1:1 correlations).

\section{DISCUSSION}

Here we demonstrate that both the native $C$. virginica and the non-native $\mathrm{O}$. edulis produce significant amounts of $\mathrm{N}_{2} \mathrm{O}$ and $\mathrm{CO}_{2}$, but not $\mathrm{CH}_{4}$. Mean annual $\mathrm{CH}_{4}$ fluxes were not statistically different between the two oysters however, they varied temporally with consumption in the fall and spring and notable pulses of production in the summer months (Figure 1B). Although not significantly different, $C$. virginica produced twice as much $\mathrm{N}_{2} \mathrm{O}$ and $\sim$ twenty times more $\mathrm{CH}_{4}$ than the non-native $O$. edulis. Further, we show that GHG fluxes and chlorophylla consumption rates were not driven by a common set of environmental parameters, nor did fluxes vary consistently with oyster characteristics. These chlorophyll consumption rates may be an underestimate as the chamber was closed and thus we did not introduce new food overtime.

Because metabolic processes scale with temperature, we anticipated GHG fluxes to be highest during warm summer months, but this pattern only held for $\mathrm{CO}_{2}$. Perhaps this is not surprising, as we measured net fluxes and thus $\mathrm{N}_{2} \mathrm{O}$ and $\mathrm{CH}_{4}$ production and consumption processes could both be stimulated by warmer temperatures. Regardless, the overall net effect of temperature on $\mathrm{N}_{2} \mathrm{O}$ and $\mathrm{CH}_{4}$ fluxes appears to be zero, an effect previously observed for sediment $\mathrm{N}_{2} \mathrm{O}$ fluxes (Foster and Fulweiler, 2016). Instead, we observed highest $\mathrm{N}_{2} \mathrm{O}$ fluxes at the intermediate temperatures during March and September, suggesting that during these time periods other factors may be more important in regulating oyster $\mathrm{N}_{2} \mathrm{O}$ flux. For example, Gárate et al. (2019) found that the addition of DIN to incubations of $C$. virginica more than tripled rates of $\mathrm{N}_{2} \mathrm{O}$ release. Previous research has proposed that $\mathrm{N}_{2} \mathrm{O}$ is released from bivalves due to inefficient nitrification in the shell biofilm (Rossong et al., 2006; Svenningsen et al., 2012; Heisterkamp et al., 2013;
Ray et al., 2019a), or as a byproduct of denitrification in the gut (Stief et al., 2009; Heisterkamp et al., 2010; Svenningsen et al., 2012; Ray et al., 2019a). Sediment $\mathrm{N}_{2} \mathrm{O}$ fluxes also increase with higher concentrations of DIN in the water column as nitrification and denitrification become less efficient (Seitzinger and Nixon, 1985; Beaulieu et al., 2011). In this study, we did not measure DIN concentrations in the site water. However, we can estimate periods of high DIN at our sampling sites using daily discharge data from the closest United States Geological Survey gage (USGS 01105870) located on the Jones River, which empties into Duxbury Bay. River discharge is typically positively correlated with DIN loading to estuaries (e.g., Fulweiler and Nixon, 2005). The period of highest river discharge-and therefore likely highest DIN loading-during the course of our study was in March 2018. This was followed by a decrease in discharge through the summer months, and another peak in discharge in September 2018. These times also correspond with the highest oyster $\mathrm{N}_{2} \mathrm{O}$ emissions we measured. Further, we recorded a significant negative correlation between $\mathrm{N}_{2} \mathrm{O}$ flux and salinity for C. virginica. Thus, we hypothesize that during periods of relatively low salinity, riverine water that is higher in DIN drives the emission of $\mathrm{N}_{2} \mathrm{O}$ from both the native and non-native oyster, and suggest that in estuarine systems, seasonal patterns of DIN loading from river discharge are more important in regulating oyster $\mathrm{N}_{2} \mathrm{O}$ release than temperature or oyster species.

Similar to $\mathrm{N}_{2} \mathrm{O}, \mathrm{CH}_{4}$ fluxes were not predicted by temperature alone, though fluxes of the largest magnitude, regardless of release or uptake, occurred during the warmest incubations. We have a poor understanding of how bivalves regulate $\mathrm{CH}_{4}$ fluxes, and the conditions that promote or inhibit $\mathrm{CH}_{4}$ release. We know that the Baltic Clam (Limecola balthica), hosts archaeal methanogenic symbionts inside its gut cavities (Bonaglia et al., 
2017), and deep-sea mussels (Bathymodiolus thermophilus) have methanotrophic symbionts in their mantle cavities (Childress et al., 1986), demonstrating that microbes responsible for regulating $\mathrm{CH}_{4}$ in marine environments do associate with bivalves. Our results show that there is both production and consumption of $\mathrm{CH}_{4}$ by oysters, yet the environmental drivers of these processes are unclear. It is likely that microbiallymediated methanogenesis and methanotrophy both proceed simultaneously in oysters, and occurrences of $\mathrm{CH}_{4}$ release or uptake are due to environmental conditions turning these pathways on or off. We recorded a significant positive correlation between $\mathrm{CO}_{2}$ and $\mathrm{CH}_{4}$ release in $\mathrm{C}$. virginica, suggesting that when more $\mathrm{CO}_{2}$ is present (and less $\mathrm{O}_{2}$ is available) near the oyster, oxygen levels are low enough to slow methanotrophy and allow some $\mathrm{CH}_{4}$ to escape. Alternatively, with lower $\mathrm{O}_{2}$, methanogenesis may become more rapid, with no change in methanotrophy.

Ray et al. (2019b) measured GHG emissions from C. virginica and the sediments beneath them, and then compared the $\mathrm{CO}_{2}$ equivalent cost per $\mathrm{g}$ protein from oysters with terrestrial livestock. In their estimation, which only required $\mathrm{N}_{2} \mathrm{O}$ and $\mathrm{CH}_{4}$ emissions from the oyster as $\mathrm{CO}_{2}$ from respiration is not included in estimates of other animal GHG release, they assumed that $\mathrm{N}_{2} \mathrm{O}$ and $\mathrm{CH}_{4}$ release from oysters was highest in the summer, and used summer GHG release values across the whole lifecycle of the oyster as a conservative approach. They estimated an oyster $\mathrm{GHG}$ cost of $0.13 \mathrm{~kg} \mathrm{CO}_{2}$-eq $\mathrm{kg}_{\text {protein }}{ }^{-1}$. While their approach was correct for assuming no difference in flux due to temperature, here we demonstrate that $\mathrm{N}_{2} \mathrm{O}$ and $\mathrm{CH}_{4}$ emissions do not necessarily proceed most rapidly during warm summer months. While the mean rate of $\mathrm{N}_{2} \mathrm{O}$ release in this study $\left(0.39 \mathrm{nmol} \mathrm{g} \mathrm{DTW}^{-1} \mathrm{hr}^{-1}\right)$ is relatively close to that reported by Ray et al. (2019a: $0.12 \mathrm{nmol} \mathrm{g} \mathrm{DTW}^{-1} \mathrm{hr}^{-1}$ ), it is slightly higher due to the spring and fall samples. Similarly, Ray et al. (2019b) reported a flux of 0 for $\mathrm{CH}_{4}$. Yet in this study we measured instances of release and consumption, and only reported a value of zero for $C$. virginica as the $p$-value comparing the $\mathrm{CH}_{4}$ flux against zero was equal to 0.06 , instead of the $\leq 0.05$ value we selected as "statistically significant" before beginning the experiment. If we use the slightly higher mean values reported in this study and the same methods as Ray et al. (2019b), who estimated a GHG cost of $0.13 \mathrm{~kg} \mathrm{CO}_{2}$-eq $\mathrm{kg}$ protein $^{-1}$, we estimate that C. virginica has a GHG cost of $1.3 \mathrm{~kg}$ $\mathrm{CO}_{2}$-eq $\mathrm{kg}_{\text {protein }}{ }^{-1}$ and $O$. edulis has a GHG cost of $0.52 \mathrm{~kg}$ $\mathrm{CO}_{2}$-eq $\mathrm{kg}$ protein ${ }^{-1}$. While higher than the previous estimate, these values are still much lower than the GHG cost of beef, which is $465.5 \mathrm{~kg} \mathrm{CO}_{2}$-eq $\mathrm{kg}_{\text {protein }}{ }^{-1}$ (Opio et al., 2013; ARS, 2018; Ray et al., 2019b). It is likely that $\mathrm{N}_{2} \mathrm{O}$ releases by oysters is only a small portion of their nitrogen budget (Ray et al., 2019a). Additionally, the $\mathrm{CH}_{4}$ observed emissions were $<0.01 \%$ of the average $\mathrm{CO}_{2}$ emissions and generally, oyster reefs are net carbon sinks (Dame et al., 1989).

This study adds to our overall understanding of the role oysters in general, and a native vs. non-native oyster species in particular, play in regulating GHG emissions from coastal ecosystems. It demonstrates that, at least in terms of GHG fluxes, the non-native oyster species appears to produce less GHGs compared to the native species. This study is just a first step in understanding how oysters alter estuarine GHG emissions. Future research could address how oyster mediated GHG fluxes vary with changes in oyster physiology and behavior, as well as with different ecosystem parameters (e.g., seasonal nutrient concentrations and phytoplankton assemblages). Overall, this study highlights that ecological impacts of non-native species introductions are complex and vary by the ecological parameter being studied.

\section{DATA AVAILABILITY STATEMENT}

The datasets generated for this study are available on request to the corresponding author.

\section{AUTHOR CONTRIBUTIONS}

RF provided the funding and facilities for this research. GM and NR completed the field, laboratory, and data analyses. All authors designed the research, contributed to writing and editing of this manuscript, and agree to be listed and accept responsibility for the manuscript.

\section{FUNDING}

This research was funded in part by a Rhode Island Sea Grant award to RF, as well as a Boston University Undergraduate Research Opportunities Program award to GM. NR was supported through a Dean's Fellowship and teaching fellowships through the Boston University Biology Department, a Boston University Marine Program Warren McLeod Research Fellowship, and a summer fellowship provided by The Frederick S. Pardee Center for the Study of the Longer-Range Future.

\section{ACKNOWLEDGMENTS}

We thank the New England Estuarine Research Society who provided a platform and helpful feedback for GM to present this research. We thank Alia Al-Haj for helping train GM on the GC and for other technical support. We also thank the Christian Horne Farm Crew and the Island Creek Shellish Farm to access to their oyster aquaculture lease for sampling. We also thank the Vincent family for establishing the Lara Vincent Research Assistance Award, which was awarded to GM and supported the publication of this manuscript.

\section{SUPPLEMENTARY MATERIAL}

The Supplementary Material for this article can be found online at: https://www.frontiersin.org/articles/10.3389/fenvs. 2019.00194/full\#supplementary-material 


\section{REFERENCES}

Anton, A., Geraldi, N. R., Lovelock, C. E., Apostolaki, E. T., Bennett, S., Cebrian, J., et al. (2019). Global ecological impacts of marine exotic species. Nat. Ecol. Evol. 3, 787-800. doi: 10.1038/s41559-019-0851-0

Arar, E. J., and Collins, G. B. (1997). Method 445.0: In Vitro Determination of Chlorophyll a and Pheophytin a in Marine and Freshwater Algae by Fluorescence. Washington, DC: United States Environmental Protection Agency, Office of Research and Development, National Exposure Research Laboratory.

Arfken, A., Song, B., Bowman, J. S., and Piehler, M. (2017). Denitrification potential of the eastern oyster microbiome using a 16S rRNA gene based metabolic inference approach. PLoS ONE 12:e0185071. doi: 10.1371/journal.pone.0185071

Bates, D., Maechler, M., Bolker, B., and Walker, S. (2015). Fitting linear mixedeffects models using lme4. J. Stat. Softw. 67, 1-48. doi: 10.18637/jss.v067.i01

Beaulieu, J. J., Tank, J. L., Hamilton, S. K., Wollheim, W. M., Hall, R. O., Mulholland, P. J., et al. (2011). Nitrous oxide emission from denitrification in stream and river networks. Proc. Natl. Acad. Sci. U.S.A. 108, 214-219. doi: 10.1073/pnas.1011464108

Bonaglia, S., Brüchert, V., Callac, N., Vicenzi, A., Chi Fru, E., and Nascimento, F. J. A. (2017). Methane fluxes from coastal sediments are enhanced by macrofauna. Sci. Rep. 7, 1-10. doi: 10.1038/s41598-017-13263-w

Byers, J. E. (2000). Competition between two estuarine snails: implications for invasions of exotic species. Ecology 81, 1225-1239. doi: 10.1890/00129658(2000)081[1225:CBTESI]2.0.CO;2

Caffrey, J. M., Hollibaugh, J. T., and Mortazavi, B. (2016). Living oysters and their shells as sites of nitrification and denitrification. Mar. Pollut. Bull. 112, 86-90. doi: 10.1016/j.marpolbul.2016.08.038

Carey, J. C., and Fulweiler, R. W. (2013). Watershed land use alters riverine silica cycling. Biogeochemistry 113, 525-544. doi: 10.1007/s10533-012-9784-2

Castro-Díez, P., Vaz, A. S., Silva, J. S., van Loo, M., Alonso, Á., Aponte, C., et al. (2019). Global effects of non-native tree species on multiple ecosystem services. Biol. Rev. 94, 1477-1501. doi: 10.1111/brv.12511

Childress, J. J., Fisher, C. R., Brooks, J. M., Kennicutt, M. C., Bidigare, R., and Anderson, A. E. (1986). A methanotrophic marine molluscan (bivalvia, mytilidae) symbiosis: mussels fueled by gas. Science 233, 1306-1308. doi: 10.1126/science.233.4770.1306

Dame, F. R., Spurrier, D. J., and Wolaver, G. T. (1989). Carbon, nitrogen and phosphorus processing by an oyster reef. Mar. Ecol. Prog. Ser. 54, 249-256.

Erler, D. V., Welsh, D. T., Bennet, W. W., Meziane, T., Hubas, C., Nizzoli, D., et al. (2017). The impact of suspended oyster farming on nitrogen cycling and nitrous oxide production in a sub-tropical Australian estuary. Estuar. Coast. Shelf Sci. 192, 117-127. doi: 10.1016/j.ecss.2017.05.007

FAO (2009). Ostrea Edulis. FAO, 1-13. Available online at: http://www.fao.org/ fishery/culturedspecies/Ostrea_edulis/en

Feinman, S. G., Farah, Y. R., Bauer, J. M., and Bowen, J. L. (2018). The influence of oyster farming on sediment bacterial communities. Estuaries Coasts 41, 800-814. doi: 10.1007/s12237-017-0301-7

Foster, S. Q., and Fulweiler, R. W. (2016). Sediment nitrous oxide fluxes are dominated by uptake in a temperate estuary. Front. Mar. Sci. 3:40. doi: 10.3389/fmars.2016.00040

Fulweiler, R. W., and Nixon, S. W. (2005). Export of nitrogen, phosphorus, and suspended solids from a southern New England watershed to Little Narragansett Bay. Biogeochemistry 76, 567-593. doi: 10.1007/s10533-005-0444-7

Fulweiler, R. W., Nixon, S. W., Buckley, B. A., and Granger, S. L. (2008). Net sediment $\mathrm{N} 2$ fluxes in a coastal marine system-experimental manipulations and a conceptual model. Ecosystems 11, 1168-1180. doi: 10.1007/s10021-008-9187-3

Galtsoff, P., Hole, W., Costello, D. P., Edwards, R. L., Henley, C., Higgins, E., et al. (1964). The American Oyster, 1964. Fish. Bull. 64, 1-458.

Gárate, M., Moseman-Valtierra, S., and Moen, A. (2019). Potential nitrous oxide production by marine shellfish in response to warming and nutrient enrichment. Mar. Pollut. Bull. 146, 236-246. doi: 10.1016/j.marpolbul.2019.06.025

Giblin, A. E., Hopkinson, C. S., and Tucker, J. (1997). Benthic metabolism and nutrient cycling in Boston Harbor, Massachusetts. Estuaries 20, 346-364. doi: $10.2307 / 1352349$
Green, D. S., Boots, B., and Crowe, T. P. (2012). Effects of non-indigenous oysters on microbial diversity and ecosystem functioning. PLoS ONE 7:e0048410. doi: 10.1371/journal.pone.0048410

Grosholz, E. D. (2005). Recent biological invasion may hasten invasional meltdown by accelerating historical introductions. Proc. Natl. Acad. Sci. U.S.A. 102, 1088-1091. doi: 10.1073/pnas.0308547102

Heiss, E. M., Fields, L., and Fulweiler, R. W. (2012). Directly measured net denitrification rates in offshore New England sediments. Cont. Shelf Res. 45, 78-86. doi: 10.1016/j.csr.2012.06.002

Heisterkamp, I. M., Schramm, A., De Beer, D., and Stief, P. (2010). Nitrous oxide production associated with coastal marine invertebrates. Mar. Ecol. Prog. Ser. 415, 1-9. doi: 10.3354/meps 08727

Heisterkamp, I. M., Schramm, A., Larsen, L. H., Svenningsen, N. B., Lavik, G., de Beer, D., et al. (2013). Shell biofilm-associated nitrous oxide production in marine molluscs: processes, precursors and relative importance. Environ. Microbiol. 15, 1943-1955. doi: 10.1111/j.1462-2920.2012.02823.x

Helmer, L., Farrell, P., Hendy, I., Harding, S., Robertson, M., and Preston, J. (2019). Active management is required to turn the tide for depleted Ostrea edulis stocks from the effects of overfishing, disease and invasive species. PeerJ 7, 1-26. doi: $10.7717 /$ peerj.6431

Hopkinson, C. S., Giblin, A. E., Tucker, J., and Garritt, R. H. (1999). Benthic metabolism and nutrient cycling along an estuarine salinity gradient. Estuaries 22, 863-881. doi: 10.2307/1353067

Kling, G. W., Kipphut, G. W., and Miller, M. C. (1991). Arctic lakes and streams as gas conduits to the atmosphere : implications for tundra carbon budgets. Science 251, 298-301. doi: 10.1126/science.251.4991.298

Kochmann, J., Buschbaum, C., Volkenborn, N., and Reise, K. (2008). Shift from native mussels to alien oysters: differential effects of ecosystem engineers. J. Exp. Mar. Bio. Ecol. 364, 1-10. doi: 10.1016/j.jembe.2008.05.015

Krassoi, F. R., Brown, K. R., Bishop, M. J., Brendan, P., and Summerhayes, S. (2008). Condition-specific competition allows coexistence of competitively superior exotic oysters with native oysters. J. Anim. Ecol. 77, 5-15. doi: 10.1111/j.1365-2656.2007.01316.x

Laing, I., Walker, P., and Areal, F. (2006). Return of the native-is European oyster (Ostrea edulis) stock restoration in the UK feasible? Aquat. Living Resour. 19, 283-287. doi: 10.1051/alr:2006029

Lawson, N. (2011). The State of Duxbury Bay 2009. Available online at: https://www.town.duxbury.ma.us/sites/duxburyma/files/uploads/duxbury_ bay_management_study_2009.pdf

Lenth, R. (2018). emmeans: Estimated Marginal Means, Aka Least-Squares Means. $\mathrm{R}$ package version 1.2.3.

Marie, A., Delignette-muller, L., Dutang, C., Denis, J., and Delignette-muller, M. M. L. (2015). Fitdistrplus: an R package for fitting fistributions. J. Stat. Softw. 64, 1-34. doi: 10.18637/jss.v064.i04

Molnar, J. L., Gamboa, R. L., Revenga, C., and Spalding, M. D. (2008). Assessing the global threat of invasive species to marine biodiversity. Front. Ecol. Environ. 6:64. doi: 10.1890/070064

Myhre, G., Shindell, D., Breon, F.-M., Collins, W., Fuglestvedt, J., Huang, J., et al. (2013). "Anthropogenic and natural radiative forcing," in Climate Change 2013: The Physical Science Basis. Contribution of Working Group 1 to the Fifth Assessment Report of the Intergovernmental Panel on Climate Change, eds. T. F. Stockner, D. Qin, G.-K. Plattner, M. Tignor, S. K. Allen, J. Boschung, et al. (Cambridge; New York, NY: Cambridge University Press), 659-740.

Opio, C., Gerber, P., Mottet, A., Falcucci, A., Tempio, G., MacLeod, M., et al. (2013). Greenhouse Gas Emissions from Ruminant Supply Chains-A Global Life Cycle Assessment. Rome: Food and Agriculture Organization of the United Nations. Available online at: http://www.fao.org/3/i3461e/i3461e00.htm

Prairie, Y. T. (1996). Evaluating the predictive power of regression models. Can. J. Fish. Aquat. Sci. 53, 490-492. doi: 10.1139/f95-204

Ray, N., Henning, M., and Fulweiler, R. (2019a). Nitrogen and phosphorus cycling in the digestive system and shell biofilm of the eastern oyster (Crassostrea virginica). Mar. Ecol. Prog. Ser. 621, 95-105. doi: 10.3354/meps13007

Ray, N. E., Maguire, T. J., Al-Haj, A. A., Henning, M., and Fulweiler, R. W. (2019b). Low greenhouse gas emissions from oyster aquaculture. Environ. Sci. Technol. 53, 9118-9127. doi: 10.1021/acs.est.9b02965

Rossong, M. A., Williams, P. J., Comeau, M., Mitchell, S. C., and Apaloo, J. (2006). Agonistic interactions between the invasive green crab, Carcinus maenas (Linnaeus) and juvenile American lobster, Homarus 
americanus (Milne Edwards). J. Exp. Mar. Bio. Ecol. 329, 281-288. doi: 10.1016/j.jembe.2005.09.007

Seebens, H., Briski, E., Ghabooli, S., Shiganova, T., MacIsaac, H. J., and Blasius, B. (2019). Non-native species spread in a complex network: the interaction of global transport and local population dynamics determines invasion success. Proc. R. Soc. B Biol. Sci. 286:20190036. doi: 10.1098/rspb.2019.0036

Seitzinger, S. P., and Nixon, S. W. (1985). Eutrophication and the rate of denitrification and N20 production in coastal marine sediments. Limnol. Oceanogr. 30, 1332-1339. doi: 10.4319/lo.1985.30.6.1332

Souchu, P., Vaquer, A., Collos, Y., Landrein, S., and Bibent, B. (2001). Influence of shellfish farming activities on the biogeochemical composition of the water column in Thau lagoon. Mar. Ecol. Process Ser. 218, 141-152. doi: $10.3354 /$ meps 218141

Sousa, R., Gutiérrez, J. L., and Aldridge, D. C. (2009). Non-indigenous invasive bivalves as ecosystem engineers. Biol. Invasions 11, 2367-2385. doi: 10.1007/s10530-009-9422-7

Stief, P., Poulsen, M., Nielsen, L. P., Brix, H., and Schramm, A. (2009). Nitrous oxide emission by aquatic macrofauna. Proc. Natl. Acad. Sci. U.S.A. 106, 4296-4300. doi: 10.1073/pnas.0808228106

Svenningsen, N. B., Heisterkamp, I. M., Sigby-Clausen, M., Larsen, L. H., Nielsen, L. P., Stief, P., et al. (2012). Shell biofilm nitrification and gut denitrification contribute to emission of nitrous oxide by the invasive freshwater mussel Dreissena polymorpha (Zebra mussel). Appl. Environ. Microbiol. 78, 4505-4509. doi: 10.1128/AEM.00401-12
ARS (2018). USDA National Nutrient Database for Standard Reference, Legacy. Beltsville, MD: Agricultural Research Service.

Vitousek, P. M., Loope, L. L., and Westbrooks, R. (1996). Biological invasions as global environmental change. Am. Sci. 84, 218-229.

Wilkie, E. M., Bishop, M. J., and Connor, W. A. O. (2012). Journal of experimental marine biology and ecology are native Saccostrea glomerata and invasive Crassostrea gigas oysters' habitat equivalents for epibenthic communities in south-eastern Australia? J. Exp. Mar. Bio. Ecol. 420-421, 16-25. doi: 10.1016/j.jembe.2012.03.018

Zwerschke, N., Emmerson, M. C., Roberts, D., and Connor, N. E. O. (2016). Benthic assemblages associated with native and non-native oysters are similar. MPB 111, 305-310. doi: 10.1016/j.marpolbul.2016.06.094

Conflict of Interest: The authors declare that the research was conducted in the absence of any commercial or financial relationships that could be construed as a potential conflict of interest.

Copyright (C) 2019 McCarthy, Ray and Fulweiler. This is an open-access article distributed under the terms of the Creative Commons Attribution License (CC BY). The use, distribution or reproduction in other forums is permitted, provided the original author(s) and the copyright owner(s) are credited and that the original publication in this journal is cited, in accordance with accepted academic practice. No use, distribution or reproduction is permitted which does not comply with these terms. 